\title{
Rapid start-up of the anammox process by denitrifying granular sludge and the mechanism of the anammox electron transport chain
}

\author{
Sihui Wang ${ }^{\mathrm{b}}$, Jianbo Guo ${ }^{\mathrm{a}, \mathrm{b}, *}$, Jing Lian ${ }^{\mathrm{b}}$, Huu Hao $\mathrm{Ngo}^{\mathrm{c}}$, Wenshan Guo ${ }^{\mathrm{c}}$, Yunman Liu ${ }^{\mathrm{b}}$, \\ Yuanyuan Song ${ }^{\mathrm{a}}$ \\ a Tianjin Key Laboratory of Aquatic Science and Technology, School of Environmental and Municipal Engineering, \\ Tianjin Chengjian University, Jinjing Road 26\#, Tianjin 300384, PR China \\ b School of Environmental Science and Engineering \& Pollution Prevention Biotechnology Laboratory of Hebei Province, Hebei University \\ of Science and \\ Technology, Yuhua East Road 70\#, Shijiazhuang 050018, PR China \\ c Centre for Technology in Water and Wastewater, School of Civil and Environmental Engineering, University of \\ Technology Sydney, Ultimo, NSW 2007, Australia \\ * Corresponding author at: Tianjin Key Laboratory of Aquatic Science and Tech- nology, School of Environmental and Municipal Engineering, Tianjin Chengjian \\ University, Jinjing Road 26\#, Tianjin 300384, PR China. E-mail address: jianbguo@163.com (J. Guo).
}

\begin{abstract}
This study investigated the rapid start-up of an anaerobic ammonium oxidation (anammox) reactor by inoculating denitrifying granular sludge mixed anammox bacteria. The mechanism of the anammox electron transport chain (AETC) was also studied using nine different inhibitors in batch tests. This is the first study that shortened the start-up anammox reactor time to 28 days. Nitrogen removal rates (NRRs) up to $0.72 \mathrm{~kg} /(\mathrm{m} 3 \mathrm{~d}$ ) on day 28 were achieved. Each studied inhibitor had a different binding site in the AETC. The effect of each inhibitor was determined by comparing the total nitrogen removal efficiency between the presence of an inhibitor and an appropriate control. The results confirmed that each inhibitor had various inhibition degrees that distinctly affected the AETC. Finally, the AETC mechanism was explored in detail. These findings are important for developing fast start-up processes for anammox reactors.
\end{abstract}

Keywords: Anammox; Denitrifying granular sludge; Start-up; Up-flow anaerobic sludge blanket; Anammox electron transport chain

\section{Introduction}

Since the first discovery of anaerobic ammonium oxidation (anammox) in a denitrifying fluidized bed reactor in the early 1990's, the anammox process has become a promising technology for removing nitrogen contaminants [1]. Anammox bacteria oxidize $\mathrm{NH}_{4}{ }^{+}$under anaerobic conditions using $\mathrm{NO}_{2}{ }^{-}$as an electron acceptor to produce $\mathrm{N}_{2}$ [2]. Compared with conventional biological nitrogen removal processes, the anammox process can reduce aeration by $64 \%$, exogenous electron donors by $100 \%$ and sludge production by $80-90 \%$ [3]. For these reasons, the anammox process is considered to be a novel and sustainable biological nitrogen removal technique.

More than 100 full-scale anammox plants exist around the world [4]. However, the adaption of the anammox process to the treatment of wastewaters has been difficult. A major obstacle for the application of the anammox process is the requirement of a long start-up time due to the relatively long doubling time of anammox bacteria. Therefore, methods for decreasing or shortening the start-up period of anammox reactors have been the subject of increasing interest. During the past few years, efforts to shorten the start-up time have focused on selecting suitable reactor types, trying different types of seed sludge, and using different types of bacteria carriers. Several types of seed sludge, including conventional activated sludge from municipal wastewater treatment plant (MWTP), denitrifying sludge, nitrifying sludge, and methanogenic granules, have been tested to enrich anammox bacteria. Denitrifying sludge and methanogenic granules have been shown to be more likely to achieve high anammox performance. However, the inoculation of methanogenic granules potentially leads to sludge breakdown in the initial start-up period [5]. For a rapid and successful anammox start-up process to work, a sufficient amount of seeding biomass is essential, and the inoculated biomass must be efficiently retained in the reactor. Anammox granular sludge exhibits significant advantages over flocculent sludge, especially in the aspects of enhancement of sludge retention and tolerance to fluctuation in external conditions [6].

Key enzyme activities and the growth rate of anammox bacteria are vital factors that affect the anammox process. Enhancing 
the enzymatic activities could correspondingly increase anammox bacteria activities and expedite the start-up of an anammox reactor. The anammox process involves several key enzymes that convert $\mathrm{NH}_{4}{ }^{+}$to $\mathrm{N}_{2}$, including nitrate reductase (NAR), nitrite reductase (NIR), hydrazine synthase (HZS) and hydrazine dehydrogenase $(\mathrm{HDH})$, all of which are located inside anammoxosomes [7]. As respiratory chain blockers, inhibitors can block different sites for many biological processes. A number of studies have reported that inhibitors can affect several processes, including: iron (III) reduction [8], Cr (VI) degradation [9], denitrification [10], nitrogenase and bidirectional Hox-hydrogenase [11]. Several studies have focused on the key enzymes activities of anammox bacteria in attempts to increase their activity. However, the involvement of the anammox electron transport chain (AETC) and the connection between the AETC and key enzyme remain unclear. The effects of the AETC and those of the relationship between the AETC and key enzymes on a fast start-up anammox reactor should be investigated.

The objective of this study was to hasten the start-up the anammox process by inoculating the denitrifying granular sludge mixed anammox bacteria in an upflow anaerobic sludge blanket (UASB) reactor. The cultivation process of the denitrifying granular sludge was examined, and the characteristics of the sludge were analyzed. After mixing the anammox bacteria, concentrations of $\mathrm{NH}_{4}{ }^{+}-\mathrm{N}, \mathrm{NO}_{2}{ }^{-}-\mathrm{N}$ and $\mathrm{NO}_{3}{ }^{-}-\mathrm{N}$ during the anammox performance were assessed to provide more useful information for the anammox reactor operation. The other main aim of this study was to investigate the AETC by using different inhibitors. These findings may provide details on improving the start-up of the anammox process.

\section{Materials and methods}

\subsection{Materials}

All chemicals reagents were of analytical grade. Metabolic inhibitors were purchased from Sigma (St. Louis, MO), and all other reagents were purchased from Xiandai, Ltd. (Shijiazhuang, China). The inhibitors included carbonyl cyanide 3chlorophenyl hydrazone (CCCP), sodium azide $\left(\mathrm{NaN}_{3}\right)$, capsaicin, N,N'-Dicyclohexylcarbodiimide (DCCD), quinacrine dihydrochloride $(\mathrm{QDH})$, dicumarol, cupricchloride $\left(\mathrm{CuCl}_{2}\right)$, rotenone, and antimycin A. The inhibitors concentrations were selected according to other papers [8,10-13]. The inhibition site and concentration of the inhibitors are shown in Table 1.

\subsection{Methods}

\subsubsection{Reactor operation}

A Plexiglas upflow sludge blanket (USB) reactor with a height of $60 \mathrm{~cm}$, an internal diameter of $6.8 \mathrm{~cm}$ and a working volume of $3.5 \mathrm{~L}$ was used. First, the reactor was inoculated with an activated flocculent sludge to culture denitrifying granular sludge. The activated flocculent was sourced from a municipal wastewater treatment plant located in Shijiazhuang, China. This process began with denitrified synthetic wastewater containing $\mathrm{CH}_{3} \mathrm{OH}, \mathrm{NaNO}_{3}$ and $\mathrm{KH}_{2} \mathrm{PO}_{4}$. $\mathrm{CH}_{3} \mathrm{OH}$ acted as the organic carbon, $\mathrm{NO}_{3}{ }^{-}$acted as the electron acceptor, and $\mathrm{KH}_{2} \mathrm{PO}_{4}$ acted as the anammox growth element. The C:N:P ratio was maintained at 40:10:1. Second, after the denitrifying granular sludge was matured, anammox bacteria from another anammox reactor were added to accelerate the start-up process. The biomass ratio of anammox bacteria and denitrifying granular sludge was 50:1. The reactor was operated at $35{ }^{\circ} \mathrm{C}$. The influent $\mathrm{pH}$ was controlled within the $7-7.5$ range. An opaque, black plastic film enclosure served to inhibit the growth of photosynthetic bacteria. The composition of the anammox synthetic wastewater was modified according to Trigo [14] (the followings are all measured in $\mathrm{g} / \mathrm{L}$, except for the trace element solution): $0.48-1.44\left(\mathrm{NH}_{4}\right)_{2} \mathrm{SO}_{4}, 0.48-1.44 \mathrm{NaNO}_{2}, 0.136 \mathrm{CaCl}_{2}, 0.1 \mathrm{MgSO}_{4}$, $0.03 \mathrm{KH}_{2} \mathrm{PO}_{4}$, and $0.3 \mathrm{NaHCO}_{3}$. Additionally, $1 \mathrm{~mL} / \mathrm{L}$ of a trace element solution was added, which contained (in g/L) 5.00 EDTA, $5.00 \mathrm{FeSO}_{4}, 0.43 \mathrm{ZnSO}_{4} \cdot 7 \mathrm{H}_{2} \mathrm{O}, 0.014 \mathrm{H}_{3} \mathrm{BO}_{4}, 0.99 \mathrm{MnCl}_{2} \cdot 4 \mathrm{H}_{2} \mathrm{O}, 0.25$ $\mathrm{CuSO}_{4} \cdot 5 \mathrm{H}_{2} \mathrm{O}, 0.19 \mathrm{NiCl}_{2} \cdot 6 \mathrm{H}_{2} \mathrm{O}$, and $0.24 \mathrm{CoCl}_{2} \cdot 6 \mathrm{H}_{2} \mathrm{O}$ [15].

\subsubsection{Batch test}

To ascertain the effects of different inhibitors on the anammox process, the anammox bacteria were used in batch tests with different inhibitors. The anammox bacteria were sourced from another lab-scale anammox UASB reactor with an NRRs of $6.7 \mathrm{~kg} /\left(\mathrm{m}^{3} \mathrm{~d}\right) \mathrm{cul}$ tured for over 2 years, which was also started-up using the same method of mixing denitrifying granular sludge. And the anammox bacteria volatile suspended solid (VSS) was $30.07 \mathrm{~g} / \mathrm{L}$, which was used to show the biomass of anammox bacteria. The tests were carried out in $300 \mathrm{~mL}$ serum bottles containing $300 \mathrm{~mL}$ media with $100 \mathrm{mg} / \mathrm{L} \mathrm{NH}_{4}{ }^{+}-\mathrm{N}, 100 \mathrm{mg} / \mathrm{L} \mathrm{NO}_{2}{ }^{-}-\mathrm{N}, 20 \mathrm{~g}$ anammox bacteria (wet weight) and inhibitors at different concentrations. Serum bottles were flushed with $\mathrm{N}_{2}$ for 5 min and sealed tightly with rubber caps to maintain anaerobic conditions. The media mainly comprised $\mathrm{NH}_{4}{ }^{+}-\mathrm{N}$ and $\mathrm{NO}_{2}{ }^{-}-\mathrm{N}$ in the form of $\left(\mathrm{NH}_{4}\right)_{2} \mathrm{SO}_{4}$ and $\mathrm{NaNO}_{2}$.

Biomass samples collected from the UASB reactor were washed three times with phosphate buffer solution to remove organic matter and were then washed three times with media to remove any residual nitrogen. Because the initial amounts of $\mathrm{NH}_{4}{ }^{+}-\mathrm{N}$ and $\mathrm{NO}_{2}{ }^{-}-\mathrm{N}$ were consumed within $12 \mathrm{~h}$ (i.e., 1 cycle), biomass samples collected after the first cycle were washed three times in phosphate buffer solution and media to remove inhibitors.

All serum bottles were wrapped in an opaque, black plastic film to prevent the growth of photosynthetic bacteria. The bottles were incubated on a shaker at $35{ }^{\circ} \mathrm{C}$. The $\mathrm{pH}$ of the media was adjusted to 7-7.5 with $1 \mathrm{M} \mathrm{HCl}$ or $1 \mathrm{M} \mathrm{NaOH}$. The water samples were collected every $2 \mathrm{~h}$ using a needle and syringe to monitor the concentrations of $\mathrm{NO}_{3}{ }^{-}-\mathrm{N}, \mathrm{NH}_{4}{ }^{+}-\mathrm{N}$ and $\mathrm{NO}_{2}{ }^{-}-\mathrm{N}$, and the total nitrogen removal efficiency was calculated. The inhibitory effect of each inhibitor was determined by comparing the total nitrogen removal efficiency between the samples with an inhibitor and an appropriate control (i.e., samples containing the media without an inhibitor). Two other control tests were used in the batch test: firstly, control test 1 contained inactivated anammox bacteria and the media, and secondly, control test 2 contained only the media.

\subsubsection{Analytical methods}

The water samples were centrifuged for $15 \mathrm{~min}$ at $8000 \mathrm{r} / \mathrm{min}$ to remove the insoluble particles from the supernatant. The COD, $\mathrm{NO}_{3}{ }^{-}-\mathrm{N}, \mathrm{NO}_{2}{ }^{-}-\mathrm{N}$ and $\mathrm{NH}_{4}{ }^{+}-\mathrm{N}$ concentrations were measured according to APHA (1995) standard methods [16]. A digital $\mathrm{pH}$ metre (Delta-320, China) was used for $\mathrm{pH}$ measurements.

\section{Results and discussion}

\subsection{Cultivation of denitrifying granular sludge}

The process of removing nitrogen and carbon from the cultivated denitrifying granular sludge is shown in Fig. 1. This process began with the denitrified synthetic wastewater containing $\mathrm{CH}_{3} \mathrm{OH}, \mathrm{NaNO}_{3}$ and $\mathrm{KH}_{2} \mathrm{PO}_{4}$. $\mathrm{CH}_{3} \mathrm{OH}$ acted as the organic carbon, $\mathrm{NO}_{3}{ }^{-}$acted as the electron acceptor and $\mathrm{KH}_{2} \mathrm{PO}_{4}$ acted as the anammox growth element. The upflow velocity of the UASB reactor was $0.71 \mathrm{~m} / \mathrm{h}$. The nitrogen loading rates (NLRs) increased from $0.69 \mathrm{~kg} /\left(\mathrm{m}^{3} \cdot \mathrm{d}\right)$ to $2.06 \mathrm{~kg} /\left(\mathrm{m}^{3} \cdot \mathrm{d}\right)$ as the influent $\mathrm{NO}_{3}{ }^{-}-\mathrm{N}$ concentration gradually increased from $100 \mathrm{mg} / \mathrm{L}$ to $300 \mathrm{mg} / \mathrm{L}$. Initially the nitrate removal efficiency was $55.9 \%$ and the COD removal efficiency was $66.9 \%$, i.e., the activity of the denitrifying bacteria in 
Table 1

Inhibitors used in this study.

\begin{tabular}{|c|c|c|c|}
\hline Chmical inhibitor & Site of inhibition & Concentration (mM) & Reference \\
\hline Capsaicin & NADH dehydrogenase (Complex I) & $0,0.2,0.5,0.8$ & [8] \\
\hline Rotenone & NADH dehydrogenase (Complex I) & $0,0.04,0.1,0.2$ & [8] \\
\hline $\mathrm{CuCl}_{2}$ & The prosthetic group (Fe-S protein) of NADH dehydrogenase & $0,0.02,0.1,0.2$ & [13] \\
\hline QDH & FAD dehydrogenase (Complex II) & $0,0.02,0.2,0.4$ & [8] \\
\hline Dicumarol & Quinone loop & $0,0.02,0.04,0.08$ & [8] \\
\hline Antimycin A & Complex III & $0,0.004,0.02,0.04$ & [8] \\
\hline $\mathrm{NaN}_{3}$ & Cytochrome oxidase (Complex IV) & $0,0.04,0.2,0.4$ & {$[10]$} \\
\hline DCCD & ATPase & $0,0.2,0.5,0.8$ & [12] \\
\hline СССР & Proton transport & $0,0.01,0.02,0.04$ & [11] \\
\hline
\end{tabular}

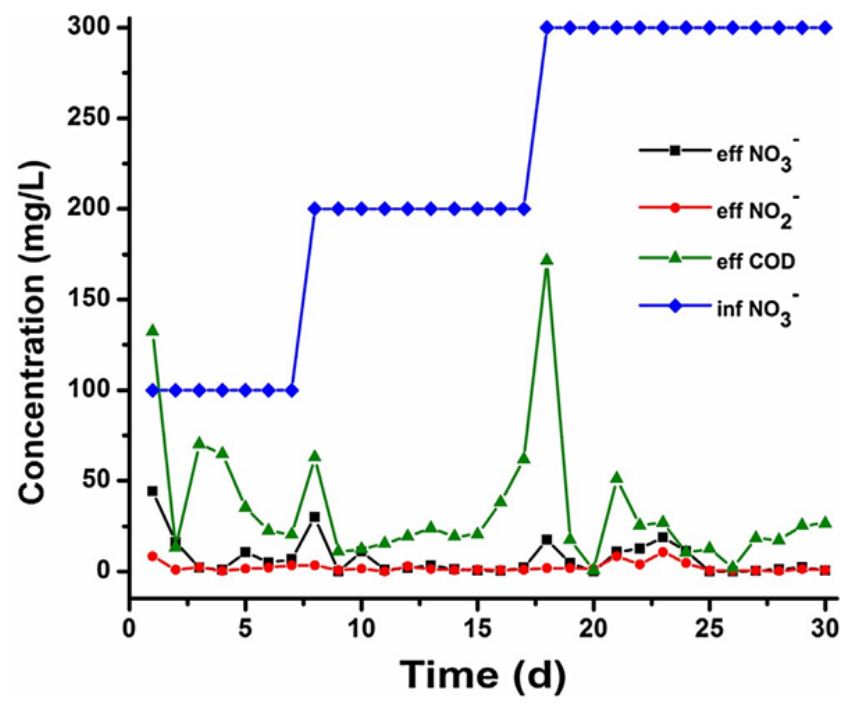

Fig. 1. The performance of nitrogen and carbon removal on the cultivation denitrifying granular sludge process in UASB reactor.

the seed sludge was poor. On day 4, the nitrate and COD removal efficiency increased to $90 \%$ and $92.5 \%$, respectively, which indicated that the amount and activity of the denitrifying bacteria had increased. On days 4-30, the effluent $\mathrm{NO}_{3}{ }^{-}$concentration was well below the established US drinking water standard of $10 \mathrm{mg} / \mathrm{L} \mathrm{[17],}$ and there was no accumulation of $\mathrm{NO}_{2}{ }^{-}$.

The characteristics of the denitrifying granular sludge are listed in Supporting information Fig. S1 in the online version at DOI: 10. 1016/j.bej.2016.09.001. The seed activated sludge was flocculent with a dark brown color. The flocculent sludge formed finer sandlike particles with a pale brown color on day 12, and the mean diameter of the sludge in the reactor was $1-1.5 \mathrm{~mm}$. After 30 days of cultivation, the granular diameter was approximately $2-4 \mathrm{~mm}$ with a white color and the wet density was $1.695 \mathrm{~g} / \mathrm{cm}^{3}$. Due to the high wet density, the settling velocity of the mature denitrifying granular sludge was $173.5 \pm 15.5 \mathrm{~m} / \mathrm{h}$. This was higher than the values of $18-100 \mathrm{~m} / \mathrm{h}$ reported in the literature [18]. The large granular diameter and good settling velocity indicated that the cultivation of denitrifying granular sludge was successfully achieved, and the denitrifying granular sludge was mature.

\subsection{Fast start-up of the anammox process}

The use of mature denitrifying granular sludge expedited the start-up of the anammox process in the UASB reactor. The biomass ratio of denitrification and anammox was 50:1. The reactor was initiated by increasing stepwise the influent $\mathrm{NH}_{4}{ }^{+}-\mathrm{N}$ and $\mathrm{NO}_{2}{ }^{-}$ $\mathrm{N}$ concentrations as shown in Fig. 2. Based on the ammonium removal, the start-up of the anammox process was divided into

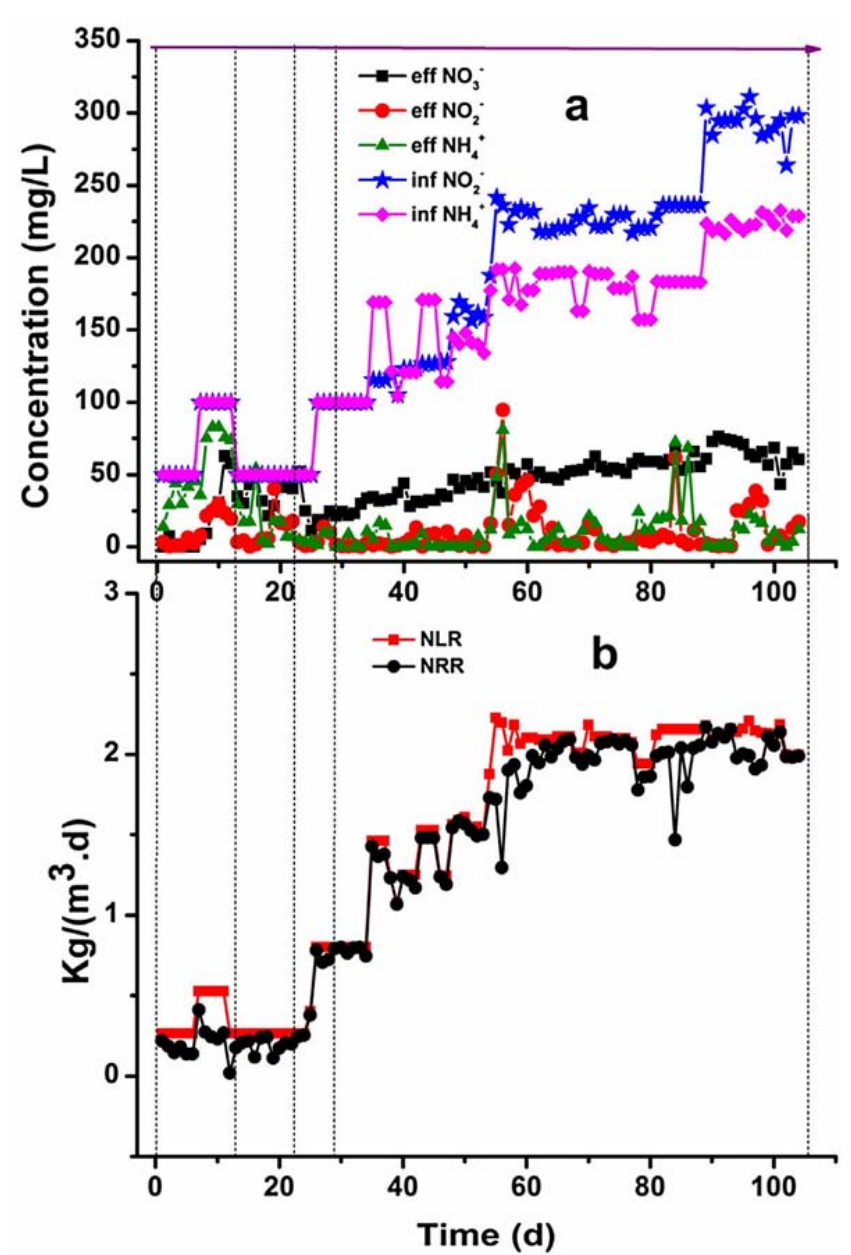

Fig. 2. Start-up performance of the anammox reactor. (a) Influent concentrations of ammonium and nitrite, effluent concentrations of ammonium, nitrite and nitrate; (b) nitrogen loading rates (NLRs) and nitrogen removal rates (NRRs).

four phases: a cell lysis phase, a lag phase, an activity elevation phase and a stationary phase [19].

Low ammonium removal was observed during the cell lysis phase (days 1-13). After mixing, the reactor was continuously fed with anammox synthetic wastewater to enrich the anammox bacteria. $\mathrm{NH}_{4}{ }^{+}$and organic matter were released from the autolysis of the denitrifying bacteria due to the initial adverse conditions of the reactor [20]. Thus, the $\mathrm{NH}_{4}{ }^{+}$removal was extremely low during the cell lysis phase. However, because of the presence of mixed anammox bacteria, which were able to consume some of the released $\mathrm{NH}_{4}{ }^{+}$, the effluent $\mathrm{NH}_{4}{ }^{+}$concentration did not exceed that of the influent, indicating the superiority of our start-up strategy. The remaining denitrifying bacteria reduced $\mathrm{NO}_{3}{ }^{-}$and $\mathrm{NO}_{2}{ }^{-}$ with the released organic matter from autolysis acting as electron 


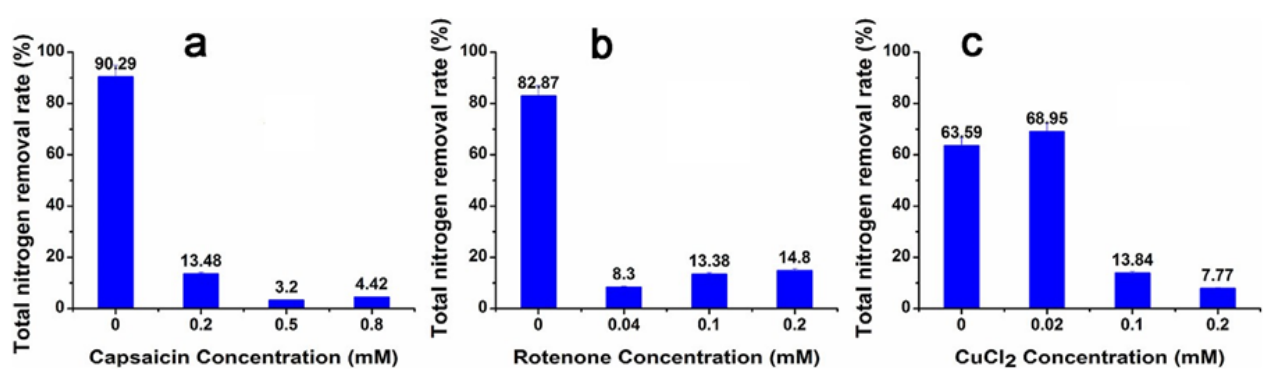

Fig. 3. Effects of inhibitors on Complex I. (a) Capsaicin; (b) rotenone; (c) $\mathrm{CuCl}_{2}$.

donors. $\mathrm{NO}_{2}-$ molecules were also reduced by the anammox bacteria. The effluent $\mathrm{NO}_{2}{ }^{-}-\mathrm{N}$ concentration was lower than $5 \mathrm{mg} / \mathrm{L}$ in this phase. The concentration of the produced $\mathrm{NO}_{3}{ }^{-}-\mathrm{N}$ was nearly 0 . On day 14 , the ammonium removal efficiency increased to $66.15 \%$ which suggested that the activity of anammox bacteria increased. From days $7-11$, the influent $\mathrm{NH}_{4}{ }^{+}-\mathrm{N}$ and $\mathrm{NO}_{2}{ }^{-}-\mathrm{N}$ concentrations increased to $100 \mathrm{mg} / \mathrm{L}$. The weak activities of the anammox bacteria resulted in high effluent $\mathrm{NH}_{4}{ }^{+}-\mathrm{N}$ and $\mathrm{NO}_{2}{ }^{-}-\mathrm{N}$ concentrations; thus, the influent $\mathrm{NH}_{4}{ }^{+}-\mathrm{N}$ and $\mathrm{NO}_{2}{ }^{-}-\mathrm{N}$ concentrations decreased to $50 \mathrm{mg} / \mathrm{L}$.

The lag phase (days 14-23) was characterized by a fitful decrease in the effluent $\mathrm{NH}_{4}{ }^{+}$concentration. Overall, the average effluent $\mathrm{NH}_{4}{ }^{+}$concentration was lower than that of the influent. During the lag phase, the average $\mathrm{NH}_{4}{ }^{+}$removal was $80.8 \%$. The high removal efficiency of $\mathrm{NO}_{2}{ }^{-}$and low production efficiency of $\mathrm{NO}_{3}{ }^{-}$confirmed that the denitrification process and cell lysis continued in the lag phase. On day 22, the average NRRs was $0.20 \mathrm{~kg} /\left(\mathrm{m}^{3} \cdot \mathrm{d}\right)$ and the effluent $\mathrm{NO}_{3}{ }^{-}$reached $40.31 \mathrm{mg} / \mathrm{L}$, i.e., a moderate level of anammox activity.

During the activity elevation phase (days 24-28), a continuous and increasing ammonium removal rate was observed. After 28 days of cultivation, the effluent $\mathrm{NH}_{4}{ }^{+}-\mathrm{N}$ and $\mathrm{NO}_{2}{ }^{-}$- $\mathrm{N}$ concentrations were consistently lower than $10 \mathrm{mg} / \mathrm{L}$. The anammox bacteria became the predominant bacteria in the consortia, and the $\mathrm{NO}_{2}{ }^{-}$ was almost completely consumed by anammox. In this phase, the average effluent ammonium removal efficiency increased from $80.8 \%$ to $92.7 \%$ as the influent $\mathrm{NH}_{4}{ }^{+}$concentrations rose from $50 \mathrm{mg} / \mathrm{L}$ to $100 \mathrm{mg} / \mathrm{L}$. The stoichiometric molar ratio of $\mathrm{NO}_{3}{ }^{-}$production to $\mathrm{NH}_{4}{ }^{+}$consumption was $0.20-0.27$, which was similar to the theoretical stoichiometric ratio of 0.26 through the anammox process [4]. The NRRs in the effluent was $0.72 \mathrm{~kg} /\left(\mathrm{m}^{3} \mathrm{~d}\right)$ on day 28. The standard start-up NRRs for the anammox process was $0.50 \mathrm{~kg} /\left(\mathrm{m}^{3} \cdot \mathrm{d}\right)$ [21]. These results suggested that the anammox performance progressively improved, and that the anammox reactor was successfully started up on day 28.

During the stationary phase, the influent $\mathrm{NH}_{4}{ }^{+}-\mathrm{N}$ and $\mathrm{NO}_{2}{ }^{-}-\mathrm{N}$ concentrations were further improved to $220 \mathrm{mg} / \mathrm{L}$ and $300 \mathrm{mg} / \mathrm{L}$, respectively. The average effluent $\mathrm{NH}_{4}{ }^{+}-\mathrm{N}$ concentration was maintained at $10.3 \mathrm{mg} / \mathrm{L}$, and the ammonium removal efficiency was stably maintained at $94.29 \%$. The $\mathrm{NO}_{2}{ }^{-}$concentration remained steady and lower than $10 \mathrm{mg} / \mathrm{L}$. $\mathrm{NO}_{2}{ }^{-}$was effectively reduced by the anammox bacteria. The production of $\mathrm{NO}_{3}{ }^{-}$increased stepwise, and the maximum $\mathrm{NO}_{3}{ }^{-}$concentration in the effluent was $76.32 \mathrm{mg} / \mathrm{L}$. The $\mathrm{NH}_{4}{ }^{+}, \mathrm{NO}_{2}{ }^{-}$and $\mathrm{NO}_{3}{ }^{-}$stoichiometric ratio was $1: 1.36: 0.32$, i.e. nearly the same as the theoretical ratio of 1:1.32:0.26. These results indicated that the anammox reactor had reached a steady state.

Based on the above results, the start-up time of the anammox process in the UASB reactor was shortened to 28 days, and the NRRs reached $0.72 \mathrm{~kg} /\left(\mathrm{m}^{3} \mathrm{~d}\right)$ by using denitrifying granular sludge mixed with anammox bacteria as the inoculum. Li et al. [5] demonstrated that an anammox reactor was successfully started-up on day 35 . Tsushima et al. [22] observed anammox reactions after a 55-day the start-up process. Chen et al. [23] reported that an anammox reactor was successfully started-up on day 40 . In this study, an NRRs of $0.72 \mathrm{~kg} /\left(\mathrm{m}^{3} \mathrm{~d}\right)$ was achieved on day 28 during the start-up of the reactor. The short start-up time indicated the superiority of our start-up strategy.

\subsection{Effects of inhibitors on the AETC mechanism}

Several studies have focused on increasing the enzymatic activity of anammox bacteria and the fast start-up of anammox reactors. However, the mechanism of the AETC has not been clearly established. One of the aims of this study was to determine the effects of inhibitors on the AETC and its enzymes. The investigation of rapid start-up of anammox reactors using the AETC should be explored in future studies. The accelerating mechanism for redox mediators was explored using the denitrifying electron transport chain (ETC) in the denitrifying process [10]. The key enzymes activity in the anammox process was enhanced by redox mediators [24]. Thus, the anammox accelerating mechanism could also be investigated using the AETC.

In this study, the total nitrogen removal efficiency was used to investigate an influence of the inhibitors on the anammox process. Antimycin A was investigated based on the ammonium and nitrite removal efficiency. Additionally, the $\mathrm{NH}_{4}{ }^{+}-\mathrm{N}$ and $\mathrm{NO}_{2}{ }^{-}-\mathrm{N}$ concentrations were kept constant in the two control tests. The results indicated that the inactivated bacteria and the media-only controls had no effects on the batch test. In the following discussion, the two control tests results are not shown in the figures.

\subsubsection{Effects of inhibitors on complex I}

The results in Fig. 3a reveal that the anammox process was inhibited by capsaicin even at the lowest tested concentration $(0.2 \mathrm{mM}$, resulting in a total nitrogen removal efficiency of 13.48\%). Capsaicin inhibited the active site of Complex I (NADH dehydrogenase). The total nitrogen removal efficiency was $3.2 \%$ and $4.42 \%$ at $0.5 \mathrm{mM}$ and $0.8 \mathrm{mM}$, respectively. There was no obvious difference between the degrees of inhibition at $0.5 \mathrm{mM}$ and $0.8 \mathrm{mM}$. Complex I catalyzed the electron transfer from NADH to ubiquinone (CoQ) with the transfer of $4 \mathrm{H}^{+}$and the release of energy. Complex I acts as a "proton pump" driven by electron transfer. Capsaicin inhibited Complex I by binding to the active site of NADH and prevented the transfer of electrons from NADH to CoQ. This led to the inhibition of $\mathrm{NH}_{4}{ }^{+}$and $\mathrm{NO}_{2}{ }^{-}$removal. These results suggest that Complex I plays an important role in the anammox process.

Rotenone affected the anammox process as shown in Fig. $3 \mathrm{~b}$. Rotenone and capsaicin have been used as respiratory chain Complex I inhibitors (at the Q site) [25]. The total nitrogen removal efficiency gradually declined from $82.87 \%$ to $14.80 \%$ to $13.38 \%$ to $8.3 \%$ with increasing rotenone concentration. Rotenone significantly inhibited the AETC at all concentrations, and the variations in the degrees of inhibition were negligible. This outcome demonstrated that rotenone inhibited Complex I and prevented electron transfer from NADH to CoQ. Like capsaicin, rotenone disrupted the 

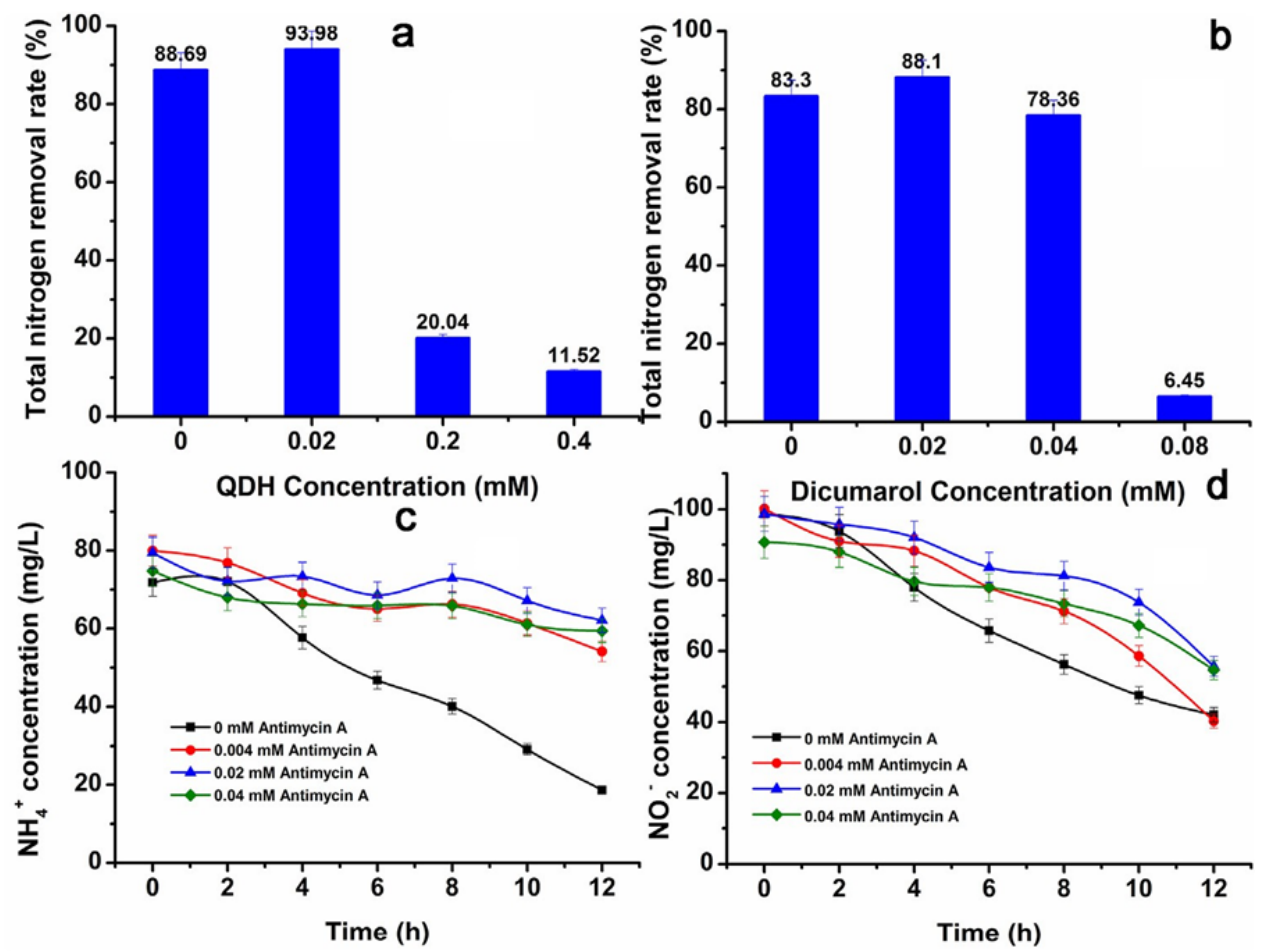

Fig. 4. Effects of inhibitors on Complex II and Complex III. (a) QDH; (b) dicumarol; (c) antimycin $\mathrm{A} \mathrm{NH}_{4}{ }^{+}$; (d) antimycin $\mathrm{A} \mathrm{NO}_{2}{ }^{-}$.

AETC and energy release, thereby decreasing the total nitrogen removal efficiency. These results were the same as those for the capsaicin experiment.

$\mathrm{Cu}^{2+}$ affected the anammox process as shown in Fig. 3c. At the lowest tested $\mathrm{Cu}^{2+}$ concentration of $0.02 \mathrm{mM}$, there was a slight increase in the total nitrogen removal efficiency, which was $5.36 \%$ higher than that of the control. This increase in the removal efficiency was due to the action of $\mathrm{Cu}^{2+}$ as an electron redox centre for shuttling electrons between different protein subunits. Many investigators have suggested that $\mathrm{Cu}^{2+}$ plays an important role as a prosthetic group in reducing enzymes [26]. The total nitrogen removal efficiency decreased to $13.84 \%$ and $7.77 \%$ as the concentration of $\mathrm{Cu}^{2+}$ increased. Thus, at higher $\mathrm{Cu}^{2+}$ concentrations, the activity of the anammox bacteria was inhibited. Heavy metals cannot be used as electron donors because they decrease the activity of the soluble enzymes [27]. When the $\mathrm{Cu}^{2+}$ concentration was $0.1 \mathrm{mM}$ and $0.2 \mathrm{mM}$, the total nitrogen removal efficiency decreased. Based on these results, it can be concluded that Complex I plays a key role in the AETC.

\subsubsection{Effects of inhibitors on complex II}

QDH affected the anammox process as shown in Fig. 4a. QDH inhibited FAD dehydrogenase. The experimental results showed that QDH had an inhibitory effect on the anammox process. However, at a QDH concentration of $0.02 \mathrm{mM}$, the total nitrogen removal efficiency was enhanced by $5.29 \%$ compared with that of the control. The total nitrogen removal efficiency was $20.04 \%$ and $11.52 \%$ at the concentrations of $0.2 \mathrm{mM}$ and $0.4 \mathrm{mM}$, respectively. The inhibition degree was more prominent at QDH concentrations of $0.2 \mathrm{mM}$ and $0.4 \mathrm{mM}$ than at $0.02 \mathrm{mM}$.

At $0.02 \mathrm{mM}$, QDH acted as either a medium (redox partner) or as an enhancer of FAD dehydrogenase in the transfer of electrons, as indicated by the relatively higher total nitrogen removal efficiency compared with the control. As the concentration increased, the ability for FAD dehydrogenase to transfer electrons was adversely inhibited by QDH. The inhibition of FAD dehydrogenase via QDH blocked the electron transfer channel, leading to a decreased total nitrogen removal efficiency. These results indicate that FAD dehydrogenase participates in the AETC.

\subsubsection{Effects of inhibitors on complex III}

Dicumarol, a quinone analogue inhibitor, blocks the transfer of electrons to menaquinone and is often used as an inhibitor of the quinone loop [28]. However, as shown in Fig. 4b, there were no obvious differences between the total nitrogen removal efficiency at the $0.02 \mathrm{mM}$ and $0.04 \mathrm{mM}$ compared with the control. Consequently, there was likely an alternative electron transport pathway separate from the quinone loop to the next electron carrier of NAR. The degree of inhibition was the most severe at $0.08 \mathrm{mM}$. These data indicate that the quinone loop participates in the AETC.

The antimycin A experiments showed that antimycin A slightly inhibited $\mathrm{NO}_{2}{ }^{-}$reduction (Fig. 4d) and heavily inhibited $\mathrm{NH}_{4}{ }^{+}$oxidation (Fig. 4c). The ammonium and nitrite removal efficiency were further explored. Antimycin A inhibited the active site of Complex III and blocked electron transport from cytochrome b to cytochrome c [29]. Moreover, the NIR reduced $\mathrm{NO}_{2}{ }^{-}$to $\mathrm{NO}$, and the HZS oxidized $\mathrm{NH}_{4}{ }^{+}$to $\mathrm{N}_{2} \mathrm{H}_{4}$. When the antimycin A was added to the system, the enzymes located in front of Complex III were slightly inhibited. Thus, Complex III is located in front of the HZS and after the NIR. The findings of Kartal [30] also show that Complex III is located after the HZS, similar to the results of this study.

\subsubsection{Effects of inhibitors on complex IV}

Sodium azide $\left(\mathrm{NaN}_{3}\right)$ affected the anammox process as shown in Fig. 5a. Sodium azide inhibited Complex IV (cytochrome oxidase) [8]. The total nitrogen removal efficiency was $90.02 \%, 49.55 \%, 39.7 \%$ and $26.72 \%$ as the $\mathrm{NaN}_{3}$ concentration increased. The degree of inhibition increased with increasing $\mathrm{NaN}_{3}$ concentration. Complex IV catalyzed the transfer of electrons from cytochrome c to $\mathrm{O}_{2}$. For each oxygen molecule reduced by cytochrome c oxidase, $4 \mathrm{H}^{+}$were transported across the membrane to the intermembrane space. Sodium azide has been shown to be an inhibitor of cytochrome oxidase and has also been linked with preventing aerobic oxidation [31]. Due to the inhibition of electron transfer at the terminal 


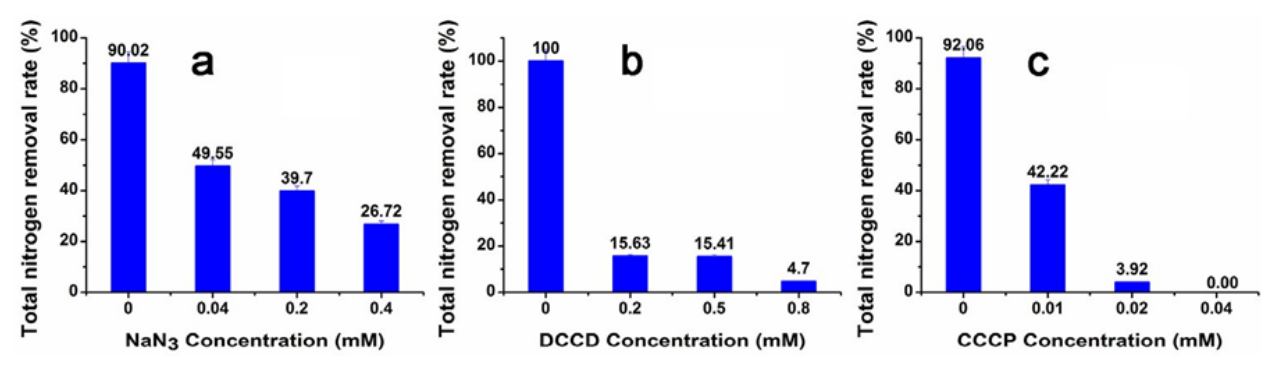

Fig. 5. Effects of inhibitors on Complex IV and other sites. (a) $\mathrm{NaN}_{3}$; (b) DCCD; (c) CCCP.

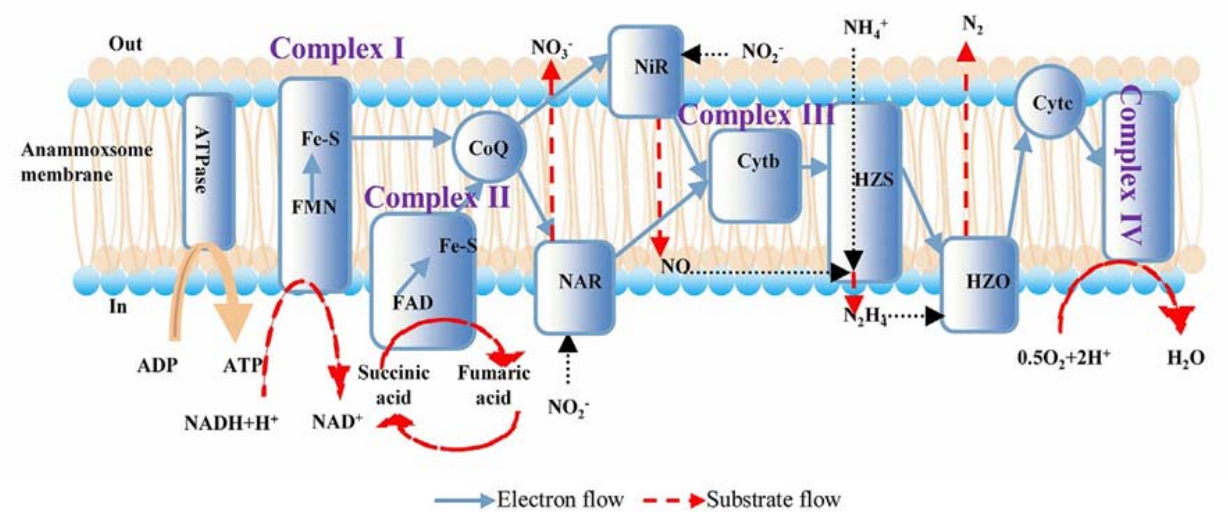

Fig. 6. The supposed mechanism of the AETC.

donor, less energy was produced by ATPase, and the activity of the anammox bacteria decreased. These results showed that Complex IV is involved in the AETC. $\mathrm{NaN}_{3}$ prevented the transfer of electrons from cytochrome $\mathrm{c}$ to the final electron acceptor (oxygen). However, because the anammox process converts $\mathrm{NH}_{4}{ }^{+}$into $\mathrm{N}_{2}$ and the process can alternatively use $\mathrm{NO}_{2}{ }^{-}$as the terminal electron acceptor in the absence of $\mathrm{O}_{2}$, nitrogen was still removed even at the highly inhibiting sodium azide concentration of $0.4 \mathrm{mM}$.

\subsubsection{Effects of inhibitors on other sites}

As illustrated in Fig. 5b, the total nitrogen removal efficiency sharply decreased with increasing DCCD. DCCD inactivated the function of ATPase by inhibiting proton translocation through the $F_{0}$ subunit of the enzyme [32]. As the DCCD concentration increased, the total nitrogen removal efficiency decreased. The lowest total nitrogen removal efficiency was $4.7 \%$ at $0.8 \mathrm{mM}$ DCCD. Racker proved [33] that ATP synthase consists of $F_{0}$ and $F_{1}$ subunits. When $\mathrm{H}^{+}$traverses the proton channel and is returned to the mitochondrial matrix, the released energy promotes the synthesis of ATP synthase. DCCD, a fat soluble carboxyl reagent, combines with the $F_{0}$ subunit to block the proton channel and inhibit the activity of ATPase. The distinct inhibition of the total nitrogen removal efficiency in the presence of DCCD indicates the involvement of ATPase in the anammox process. In the Van Niftrik et al. [34] study, the ATPase was associated with the anammox membranes which the result was same with our investigation.

The CCCP impact on the anammox process is depicted in Fig. 5c. CCCP uncoupled the proton pump mechanism from the mitochondrial membrane, resulting in a disruption of proton transport across the membrane [35]. The total nitrogen removal efficiency fell sharply to $42.22 \%$ at $0.01 \mathrm{mM} \mathrm{CCCP.} \mathrm{The} \mathrm{total} \mathrm{nitrogen} \mathrm{removal}$ efficiency was $3.92 \%$ at $0.02 \mathrm{mM}$ CCCP. The anammox process was completely inhibited at $0.04 \mathrm{mM}$. A chemiosmotic hypothesis was proposed by Mitchell [36], which suggested that most ATP synthesis in respiring cells originates from an electrochemical gradient across the inner membranes of the mitochondria through the use of $\mathrm{NADH}$ and $\mathrm{FADH}_{2}$ and forms from the breakdown of energyrich molecules such as glucose. The spent energy produces a proton gradient based on the electron transfer process. The proton gradient across the membrane produces a "proton-motive force" (pmf), and ATP synthase uses the pmf across the membrane to drive the synthesis of ATP from ADP.CCCP disrupts this pmf, resulting in less ATP synthesis [37]. In this experiment, the reduced enzyme activity inhibited the anammox process.

\subsubsection{Electron transport chain}

The supposed mechanism of the AETC and the key enzymes involved were explored using the different inhibitors that inhibited different sites in the anammox process. Inhibitory experiments with capsaicin, rotenone and $\mathrm{CuCl}_{2}$ demonstrated that Complex I plays an important role in the AETC. The total nitrogen removal efficiency decreased at high QDH concentrations, which indicated that Complex II was inhibited and took part in the AETC. Complex III and Complex IV were shown to participate in the anammox process using antimycin A, dicumarol and sodium azide. Moreover, in the antimycin A experiments, the inhibition of $\mathrm{NH}_{4}{ }^{+}$was higher than the inhibition of $\mathrm{NO}_{2}{ }^{-}$. This indicated that Complex III was located in front of the HZS and after the NIR. The DCCD experiment indicated that ATPase played an important role in the anammox process. Based on this study and previous investigations [30,38-40], a schematic of the mechanism of the AETC is shown in Fig. 6. These key enzymes are located in the anammoxosome membrane. The anammoxosome, an intracytoplasmic bounded compartment, is the locus of anammox catabolism. $\mathrm{N}_{2} \mathrm{H}_{4}$ was produced from ammonium and nitrite in the anammox substrates. In the anammox reaction, $\mathrm{NO}_{2}{ }^{-}$was first reduced to nitric oxide (NO) by NIR. NO then reacts with $\mathrm{NH}_{4}{ }^{+}$to yield $\mathrm{N}_{2} \mathrm{H}_{4}$ by HZS . Finally, $\mathrm{N}_{2} \mathrm{H}_{4}$ was oxidized to $\mathrm{N}_{2}$ by HZS. ATPase catalyzed the 
reaction of ADP to ATP. Complex I, Complex II, Complex III and Complex IV took part in the AETC.

\section{Conclusions}

In this study, rapid start-up of an anammox reactor can be triggered by inoculating the denitrifying granular sludge mixed with some anammox biomass. This represents the first time that the start-up time of an anammox reactor was shortened to 28 days. The NRRs reached $0.72 \mathrm{~kg} /\left(\mathrm{m}^{3} \cdot \mathrm{d}\right)$ on day 28 . The supposed mechanism of the AETC was explored. The mechanism further elucidated the anammox process. Finally, according to the mechanism, electron transfer could be accelerated by increasing the key enzymatic activities.

\section{Acknowledgements}

This study was supported by the National Natural Science Foundation of China (Grant No. 51208170, China), Program for Hundred Outstanding Innovation Talents in Hebei Universities(II)(BR2-211, China), Hebei Natural Science Foundation for Distinguished Young Scholars(Grant No.E2012208012, China) and the Science Research Program of High Level Talents in Hebei Universities (Grant No. GCC2014045, China). Thanks are extended to the Analytical \& Testing Center of Hebei. The authors are also grateful to the research collaboration between Tianjin Chengjian University and University of Technology Sydney.

\section{References}

[1] T. Lotti, R. Kleerebezem, Z. Hu, B. Kartal, M.S.M. Jetten, M.C.M. van Loosdrecht, Simultaneous partial nitritation and anammox at low temperature with granular sludge, Water Res. 66 (2014) 111-121.

[2] M. Strous, J.A. Fuerst, E.H. Kramer, S. Logemann, G. Muyzer, K.T. van de Pas-Schoonen, R. Webb, J.G. Kuenen, M.S.M. Jetten, Missing lithotroph identified as new planctomycete, Nature 400 (1999) 446-449.

[3] M.C.M. van Loosdrecht, Innovative nitrogen removal, in: M. Henze, G.A. van Loosdrecht, BD (Eds.), Biological Wastewater Treatment: Principles, Modelling and Design, IWA Publishing, London, 2008, pp. 139-154.

[4] M. Strous, J.J. Heijnen, J.G. Kuenen, M.S.M. Jetten, The sequencing batch reactor as a powerful tool for the study of slowly growing anaerobic ammonium-oxidizing microorganisms, Appl. Microbiol. Biotechnol. 50 (1998) 589-596.

[5] H.S. Li, S.Q. Zhou, W.H. Ma, G.T. Huang, B. Xu, Fast start-up of ANAMMOX reactor: operational strategy and some characteristics as indicators of reactor performance, Desalination 286 (2012) 436-441.

[6] S.Q. Ni, B.Y. Gao, C.C. Wang, J.G. Lin, S. Sung, Fast start-up, performance and microbial community in a pilot-scale anammox reactor seeded with exotic mature granules, Bioresour. Technol. 102 (2011) 2448-2454.

[7] X. Yin, S. Qiao, C. Yu, T. Tian, J.T. Zhou, Effect of reduced graphene oxide on the activities of anammox biomass and key enzymes, Chem. Eng. J. 276 (2015) $106-112$.

[8] A. Woznica, J. Dzirba, D. Manka, S. Labuzek, Effects of electron transport inhibitors on iron reduction in Aeromonas hydrophila strain KB1, Anaerobe 9 (2003) 125-130.

[9] C. Desai, K. Jain, D. Madamwar, Evaluation of In vitro Cr(VI) reduction potential in cytosolic extracts of three indigenous Bacillus sp. Isolated from Cr(VI) polluted industrial landfill, Bioresour. Technol. 99 (2008) 6059-6069.

[10] Z.H. Xi, J.B. Guo, J. Lian, H.B. Li, L.J. Zhao, X.Y. Liu, C.X. Zhang, J.L. Yang, The catalyzing mechanism of dissolved redox mediators on bio-denitrification by metabolic inhibitors, Bioresour. Technol. 140 (2013) 22-27.

[11] W. Khetkorn, W. Baebprasert, P. Lindblad, A. Incharoensakdi, Redirecting the electron flow towards the nitrogenase and bidirectional Hox-hydrogenase by using specific inhibitors results in enhanced $\mathrm{H}_{2}$ production in the cyanobacterium Anabaena siamensis TISTR 8012, Bioresour. Technol. 118 (2012) 265-271.

[12] S.K. Das, A.K. Guha, Biosorption of hexavalent chromium by Termitomyces clypeatus biomass: kinetics and transmission electron microscopic study, J. Hazard. Mater. 167 (2009) 685-691.

[13] Z. Rahman, V.P. Singh, Cr(VI) reduction by Enterobacter sp. DU17 isolated from the tannery waste dump site and characterization of the bacterium and the Cr(VI) reductase, Int. Biodeter. Biodegr. 91 (2014) 97-103.
[14] C. Trigo, J.L. Campos, J.M. Garrido, R. Mendez, Start-up of the Anammox process in a membrane bioreactor, J. Biotechnol. 126 (2006) 475-487.

[15] A.A. van de Graaf, P. de Bruijn, L.A. Robertson, M.S.M. Jetten, J.G. Kuenen, Autotrophic growth of anaerobic ammonium-oxidizing microorganisms in a fluidized bed reactor, Appl. Environ. Microbiol. 142 (1996) 2187-2196.

[16] APHA(American Public Health Association), Standard Methods for the Examination of Water and Wastewater, nineteenth ed., APHA, New York, 1995.

[17] US Environmental Protection Agency (USEPA), Nitrate/Nitrite, Health Advisory Office of Drinking Water, US Environmental Protection Agency, 1987.

[18] S. Chong, T.K. Sen, A. Kayaalp, H.M. Ang, The performance enhancements of upflow anaerobic sludge blanket (UASB) reactors for domestic sludge treatment-a state-of-the-art review, Water Res. 46 (2012) 3434-3470.

[19] N. Chamchoi, S. Nitisoravut, Anammox enrichment from different conventional sludges, Chemosphere 66 (2007) 2225-2232.

[20] C.J. Tang, P. Zheng, L. Zhang, Q. Mahmood, J.W. Chen, B.L. Hu, X.G. Chen, C.H. Wang, Y. Yu, Enrichment features of anammox consortia from methanogenic granules loaded with high organic and methanol content, Chemosphere 79 (2010) 613-619.

[21] R.C. Jin, P. Zheng, A.H. Hu, Q. Mahmood, B.L. Hu, G. Jilani, Performance comparison of two Anammox reactors: SBR and UBF, Chem. Eng. J. 138 (2008) 224-230.

[22] I. Tsushima, Y. Ogasawara, T. Kindaichi, H. Satoh, S. Okabe, Development of high-rate anaerobic ammonium-oxidizing (anammox) biofilm reactors, Water Res. 41 (2007) 1623-1634.

[23] H. Chen, H.Y. Hu, Q.Q. Chen, M.L. Shi, R.C. Jin, Successful start-up of the anammox process: influence of the seeding strategy on performance and granule properties, Bioresour. Tech. 211 (2016) 594-602.

[24] S. Qiao, T. Tian, J.T. Zhou, Effects of quinoid redox mediators on the activity of anammox biomass, Bioresour. Technol. 152 (152C) (2014) 116-123.

[25] H. Miyoshi, Structure a ctivity relationship of some complex I inhibitors, Biochim. Biophys. Acta 1364 (1998) 236-244.

[26] A.S.S. Ibrahim, M.A. El-Tayeb, Y.B. Elbadawi, A.A. Al-Salamah, G. Antranikian, Hexavalent chromate reduction by alkaliphilic Amphibacillus sp. $\mathrm{KSUCr}_{3}$ is mediated by copper-dependent membrane-associated $\mathrm{Cr}(\mathrm{VI})$ reductase, Extremophiles 16 (2012) 659-668.

[27] S. Murugavelh, K. Mohanty, Bioreduction of hexavalent chromium by free cells and cell free extracts of Halomonas sp, Chem. Eng. J. 203 (2012) 415-422.

[28] V. Knight, R. Blakmore, Reduction of diverse electron acceptors by Aeromonas hydrophila, Arch. Microbiol. 169 (1998) 239-248.

[29] H. Kim, L. Esser, M.B. Hossain, D. Xia, C.H. YU, J. Rizo, D. van der Helm, J. Deisenhofer, Structure of Antimycin $A_{1}$, a specific electron transfer inhibitor of ubiquinol-cytochrome c oxidoreductase, J. Am. Chem. Soc. 121 (1999) 4902-4903.

[30] B. Kartal, W.J. Maalcke, M. Naomi de Almeida, I. Cirpus, J. Gloerich, W. Geerts, H.J.M. Op den Camp, H.R. Harhangi, E.M. Janssen-Megens, K.J. Francoijs, H.G. Stunnenberg, J.T. Keltjens, M.S.M. Jetten, M. Strous, Molecular mechanism of anaerobic ammonium oxidation, Nature 479 (2011) 127-130.

[31] Ch. R. Myers, K.H. Nelson, Bacterial manganese reduction and growth with manganese oxide as the sole electron acceptor, Science 240 (1988) 13191321.

[32] H. Komeda, M. Kobayashi, S. Shimizu, A novel transporter involved in cobalt uptake, Proc. Natl. Acad. Sci. U. S. A. 94 (1997) 36-41.

[33] E. Racker, Biographical memoirs, Natl. Acad. Sci. 70 (1996).

[34] L. Van Niftrik, M. Van Helden, S. Kirchen, E.G. Van Donselaar, H.R. Harhangi, R.I. Webb, J.A. Fuerst, H.J.M. Op den Camp, M.S.M. Jetten, M. Strous, Intracellular localization of membrane-bound ATPases in the compartmentalized anammox bacterium 'Candidatus Kuenenia stuttgartiensis’, Mol. Microbiol. 77 (2010) 701-715.

[35] P.G. Heytler, Uncouplers of oxidative phosphorylation, Methods Enzymol. 55 (1979) 442-462.

[36] P. Mitchell, Coupling of phosphorylation to electron and hydrogen transfer by a chemiosmotic type of mechanism, Nature 191 (1961) 144-148.

[37] P. Tamagnini, E. Leitao, P. Oliveira, D. Ferreira, F. Pinto, D.J. Harris, T. Heidorn, P. Lindblad, Cyanobacterial hydrogenase: diversity, regulation and applications, FEMS Microbiol. Rev. 31 (2007) 692-720.

[38] M.T. Madigan, J.M. Martinko, D.A. Stahl, D.P. Clark, Brock Biology of Microorganisms, thirteenth ed., Benjamin Cummings, San Francisco, 2010.

[39] M. Strous, E. Pelletier, S. Mangenot, T. Rattei, A. Lehner, M.W. Taylor, M. Horn, H. Daims, D. Bartol Mavel, P. Wincker, V. Barbe, N. Fonknechten, D. Vallenet, B. Segurens, C. Schenowitz Truong, C. Medigue, A. Collingro, B. Snel, B.E. Dutilh, R.J. Op den Camp, C. van der Drift, I. Cirpus, K.T. van de Pas Schoonen, H.R. Harhangi, L. van Niftrik, M. Schmid, J. Keltjens, J. van de Vossenberg, B. Kartal, H. Meier, D. Frishman, M.A. Huynen, H.W. Mewes, J. Weissenbach, M.S. Jetten, M. Wagner, D. Le Paslier, Deciphering the evolution and metabolism of an anammox bacterium from a community genome, Nature 440 (2006) 790-794.

[40] A.A. Van de Graaf, P. deBruijn, L.A. Robertson, M.S.M. Jetten, J.G. Kuenen, Metabolic pathway of anaerobic ammonium oxidation on the basis of $\mathrm{N}-15$ studies in a fluidized bed reactor, Microbiology 143 (1997) 2415-2421. 